\title{
Ergonomic culture level in managers and supervisors in manufacturing centers
}

\section{Nivel de cultura ergonómica en supervisores y alta direccion en una empresa manufacturera}

LÓPEZ-ACOSTA, Mauricio, CHACARA-MONTES, Allán, VELARDE-CANTÚ, José Manuel and RAMIREZ-CARDENAS, Ernesto

Instituto Tecnológico de Sonora

ID $1^{\text {st }}$ Author: Mauricio, López-Acosta / ORC ID: 0000-0003-3728-9576

ID $1^{\text {st }}$ Co-Author: Allán, Chacara-Montes / ORC ID: 0000-0002-0567-0017

ID $2^{\text {nd }}$ Co-Author: José Manuel, Velarde-Cantú / ORC ID: 0000-0002-1697-8551

ID $3^{\text {rd }}$ Co-author: Ernesto Ramírez-Cárdenas / ORC ID: 00-0002-5248-724X

DOI: $10.35429 / J R D .2021 .20 .7 .21 .26$

Received July 26, 2021; Accepted October 24, 2021

\begin{abstract}
The purpose of the following project is to measure the level of ergonomic culture of a manufacturing company that is dedicated to the development of cables, fiber optics, cabling systems and related services for the automotive sector and cable systems; To carry out this study, the ergonomic culture questionnaire in work centers (CCE-T) was used as a tool and it was applied to a sample of 26 people between supervisors and managers. This questionnaire made it possible to measure the level of development of ergonomic culture in work centers from the perspective of supervisors and senior management (managers) and to know their perception of the development and application of ergonomics in their company. Therefore,
\end{abstract}

Ergonomic Culture, Management, Cultura Ergonómica, Dirección, Evaluación

\begin{abstract}
Resumen
El siguiente proyecto tiene como propósito medir el nivel de cultura ergonómica de una empresa manufacturera que se dedica a la elaboración de cables, fibra óptica, sistemas de cableados y servicio relacionados para el sector automotriz y sistemas de cable; para realizar dicho estudio se utilizó como herramienta el cuestionario de cultura ergonómica en centros de trabajo (CCE-T) y fue aplicado a una muestra de 26 personas entre supervisores y gerentes. Este cuestionario permitió medir el nivel de desarrollo de la cultura ergonómica en centros de trabajo desde la óptica de los que supervisores y la alta dirección (gerentes) y conocer la percepción que tienen sobre el desarrollo y aplicación de la ergonomía en su empresa. Por consiguiente, este instrumento se considera un elemento valioso como mecanismo de realimentación de procesos en salud colectiva y como herramienta diagnóstica.
\end{abstract}

Evaluation

Citation: LÓPEZ-ACOSTA, Mauricio, CHACARA-MONTES, Allán, VELARDE-CANTÚ, José Manuel and RAMIREZCARDENAS, Ernesto. Ergonomic culture level in managers and supervisors in manufacturing centers. Journal of Research and Development. 2021. 7-20: 21-26

$\dagger$ Researcher contributing as first author. 


\section{Introduction}

The automotive industry has a high production volume, meaning that components are assembled at a speed of 50 seconds per workstation and even when this industry is technology-based, parts of the process persist where the assemblies are manual or almost artisanal. Making the calculations based on this data and assuming that a component is assembled or used every five seconds, in total: every second 18 million components would be used, only for the industry in Mexico, this can be interpreted as that every second moving the workers' upper extremities 18 million times; fingers, hands, elbows, shoulders, neck and back (Millán, 2016).

Postural overload is an important factor for the appearance of musculoskeletal injuries in the worker, it is characterized by the fact that the body is out of the neutral position for a certain time, which favors the presence of symptoms of pain, inflammation, dysesthesia, paresthesia and limitation to carry out their work, preventing them from carrying out daily activities. (Tapia, Buenrostro, Cabrera, Pérez and Malagón (2017).

Faced with the real demand for these needs, industrial society demands from production engineering and ergonomics an effort to work together to provide solutions through concepts, methods, techniques and tools (Gomes, 2014).

The International Ergonomics Association (IEA) defines ergonomics as a scientific discipline that deals with understanding the interactions between users and other elements of a system, and the profession that applies theory, principles, data and methods to design in order to optimize the well-being and performance of the system (IEA, 2021)

In this way, the aim of ergonomics is that employees are comfortable in their workplaces. This objective is not only an ethical premise, but it will also have to do with the optimization of the usual processes of a company. If in a company the precise conditions are given so that its workers are comfortable in their positions, an increase in their performance will lead to an increase in productivity. Consequently, the company will be the main beneficiary of the implementation of ergonomic measures, which will be profitable over time (ARSAM, 2020).
Some reviews have provided data on the benefits that ergonomic interventions bring to these factors, underlining the importance of including not only workers, but also supervisors and senior management in these intervention strategies. That said, a company is then expected to develop a high degree of ergonomic culture, as the cornerstone of what is considered the primary intervention in ergonomics (Guzmán, 2010).

The term ergonomic culture is understood as "the set of forms and expressions applied to transform work, which characterize an organization" therefore, for a true ergonomic culture to exist, a "favorable environment, a thought collective and social reaffirmation of needs in the workplace "(Gómez, 2002).

Ardila \& Rodríguez, (2018) after a review of the literature, they made a theoretical construct based on the Scott, Kogi and McPhee model and that contemplates the macroergonomic and micro-ergonomic dimensions and the organizational design, facilities design, training / education components, job title, task design, equipment / products and tools. They obtained a questionnaire of 26 items with Likerttype responses, validated by 5 experts (who made adjustments for relevance and adequacy), an analysis was carried out by main components (KMO, 0.804) and with a Cronbach's alpha of 0.901 in its internal consistency. The questions are outlined so that they can be answered in any business context. The definitive name of the instrument was assigned as:

For the assignment of values, the categories taken from the Likert scale raised in the questionnaire lead the evaluator to weigh each item. Thus, the total of the totally agreed answers are multiplied by one; partially agree, by two; partially disagree, by three; and totally disagree, by four. To determine the classification, from the results the total of the sum of responses of each of the four categories is taken, and it is transferred to a weighted table that allows, finally, to give the result of the level at which the worker classifies your company.

When evaluating the level of ergonomic culture, it is expected that a company can develop four levels of ergonomic culture: low, medium, high and very high, product of the sum of the partial totals already weighted. 
This categorization allows the company to be guided on what its workers consider in terms of ergonomics actions and to compare the results with what exists.

The objective of this study is to determine the level of culture of supervisors and managers in a manufacturing company by applying the Questionnaire of Ergonomic Culture in Work Centers.

\section{Methodology to be developed}

\section{A. Study subject}

The study subjects were the supervisors and line managers of a manufacturing company. For the application of the questionnaire, it was taken into account that the company has 21 supervisors and 7 managers in all its areas from prototype, preparation, production and molding and to carry out a study a sample size calculation was made using a statistical tool, to know the number of questionnaires to be applied in order to measure the level of ergonomic culture in the company.

For the sample size, it was taken into account that it is a finite sample, with a confidence level of 95\%; Obtaining that the necessary sample size is 26 subjects (supervisors and managers) to whom the questionnaire will be applied in order to know their perception of the development and application of ergonomics.

\section{B. Procedure}

Next, the steps that were carried out for the application of the ergonomic culture questionnaire in CCE-T work centers will be described.

\section{- $\quad$ Instrument reliability}

In this activity, the reliability of the instrument was determined by determining Cronbach's Alpha.

\section{- Questionnaire application.}

In this activity, a questionnaire was applied to the supervisors and managers of the company to find out their perception of the development and application of ergonomics.

\section{- $\quad$ Analysis of results.}

According to the data collection, the responses were analyzed to know the level of ergonomic culture that the company has.

\section{Materials}

The materials used to carry out the project were the following:

\section{- $\quad$ SPSS software. \\ - Ergonomic culture questionnaire in CCE-T work centers of (Ardila \& Rodríguez, (2018).}

\section{Results and their discussion}

The applied instrument has 26 items and shows an Alpha Cronbach reliability of 0.897 , which is considered acceptable. The sample $(n=26)$ consisted mainly of 16 men $(61.5 \%)$ and 10 women $(38.5 \%)$. Their average age was 34.4 years, and $73 \%$ had a Bachelor's degree and $27 \%$ a Master's level, with an average age of 3.2 years working in the company, a minimum of 8 months and a maximum of 7 years in the company. the company, of which 19 are supervisors and 7 managers.

The maximum value registered of the level of ergonomic culture obtained a value of 60 pts and the minimum of 45 , with an average of 52.1 pts., And according to the scale used of 4052 , it considers that the Level of Culture is High, of 53-78 is Medium, and 79-104 is Low. In this way, being grouped according to level, $46 \%$ of the participants were high level and $54 \%$ of the participants medium level, see figure 1 , highlighting that the managerial level is $100 \%$ high, in table 1 the data is disaggregated by position and gender.

\begin{tabular}{|c|c|c|c|c|c|c|c|}
\hline \multirow[t]{3}{*}{ Position } & \multirow{3}{*}{$\begin{array}{c}\text { tot } \\
\text { al }\end{array}$} & \multicolumn{6}{|c|}{ Culture Level } \\
\hline & & \multicolumn{2}{|c|}{ High } & \multicolumn{2}{|c|}{ Half } & \multicolumn{2}{|c|}{ Come Down } \\
\hline & & $\mathrm{H}$ & $\mathrm{M}$ & $\mathrm{H}$ & $M$ & $\mathrm{H}$ & $\mathrm{M}$ \\
\hline Managers & 7 & 5 & 2 & 0 & 0 & 0 & 0 \\
\hline Supervisors & 19 & 2 & 3 & 9 & 5 & 0 & 0 \\
\hline & 26 & 7 & 5 & 9 & 5 & 0 & 0 \\
\hline & 10 & 26.9 & 19.2 & 34.6 & 19.2 & 0.0 & 0.0 \\
\hline Totals & $0 \%$ & $\%$ & $\%$ & $\%$ & $\%$ & $\%$ & $\%$ \\
\hline
\end{tabular}

Table 1 Level of culture by type of position and gender 


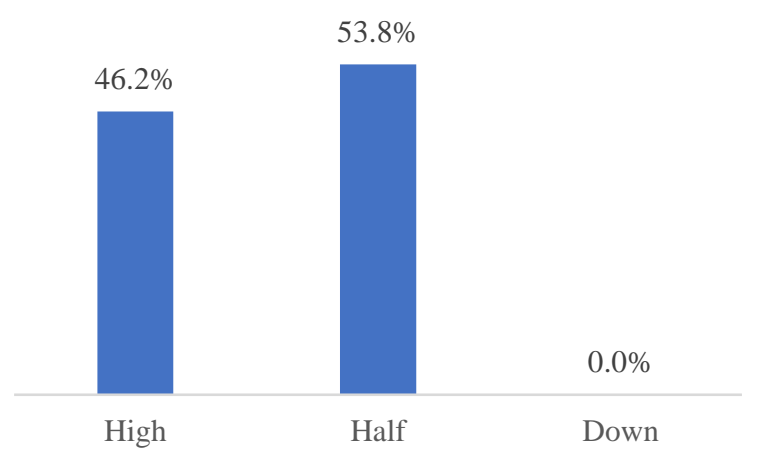

Figure 1 CCE level by category

Which means that:

High Level: The worker recognizes specific and organized actions in the development of the Ergonomic Culture in the company

Medium Level: The work recognizes some important points that denote an incipient development of an Ergonomic Culture in the company.

\section{Analysis by question of the most relevant results of the study:}

Question numberfour of the questionnaire: "Have measurements been made of the parts of your body to make adjustments to your job during the time you have been working in this company?" presents a result that shows that $100 \%$ is in "Totally disagree", this indicates that the organization does not have the anthropometric characteristics of its collaborators, which could affect decisionmaking to adjust their workstation or tools of work to your anthropometric measurements.

Question number eleven of the questionnaire: Have you received reinduction of the work you do? " presents a result that shows that $50 \%$ are in "Partially disagree" and the other $50 \%$ is "Partially agree" as shown in Figure 2, this indicates that only half of the subjects under study have received some reinduction in the work carried out in the company.

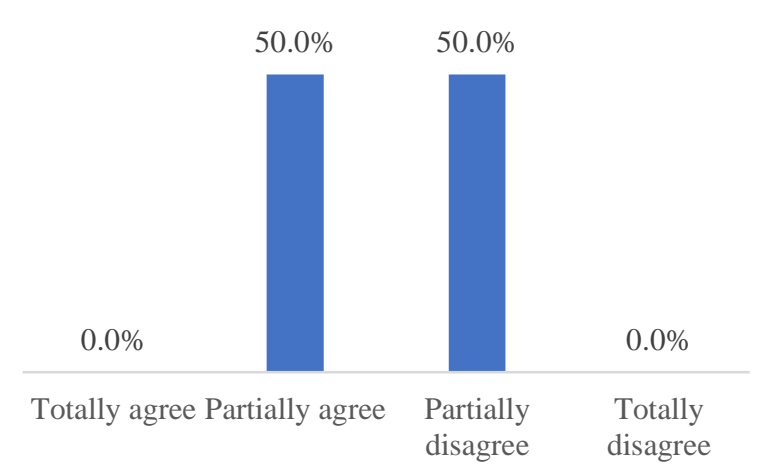

Figure 2 Percentage of reinduction of the task performed

Question number twelve of the questionnaire: "Do you receive training to improve the work you do?" presents a result that shows that $61 \%$ are in "Partially disagree", $31 \%$ are "Partially agree" and $8 \%$ are "Totally agree" as shown in Figure 3, this means that their majority of the subjects under study $(61 \%)$ do not receive adequate training to improve the work they do, while the other $(39 \%)$ receive adequate or regular training to improve the work they do.

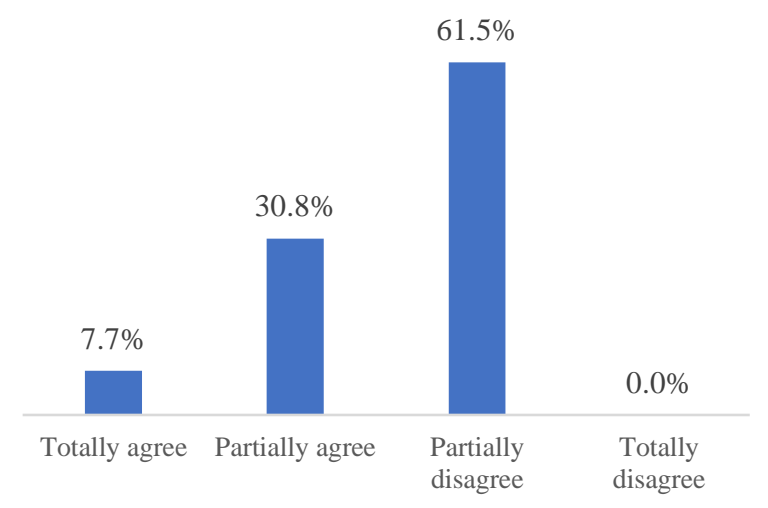

Figure 3 Percentage of training to improve the task performed

Question number seventeen of the questionnaire: "Are evaluations made of the conditions in which your physical workspace is located?" presents a result that shows that $69 \%$ agree "Partially agree" and 31\% show "Partially disagree" as shown in Figure 4, this indicates that evaluations about the conditions are not carried out frequently or regularly of the physical work space of the subjects under study. 


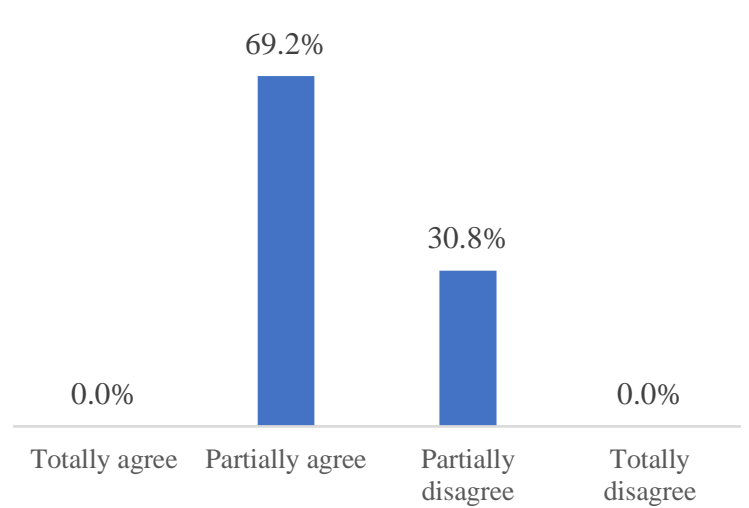

Figure 4 Percentage of people who have been considered, to improve their work area

Question number eighteen of the questionnaire: Have changes been made in the tasks that you carry out in a way that generates less risk of illness or injury? " presents a result that shows that $69 \%$ agree "Partially agree", $23 \%$ are "Partially disagree" and $8 \%$ are "Totally agree" as shown in Figure 5, this indicates that in the Most of the subjects under study have made changes in the tasks they perform on a regular basis changes in the tasks they perform in a way that generates less risk of illness or injury while only $23 \%$ show that no changes are made in the tasks regularly.

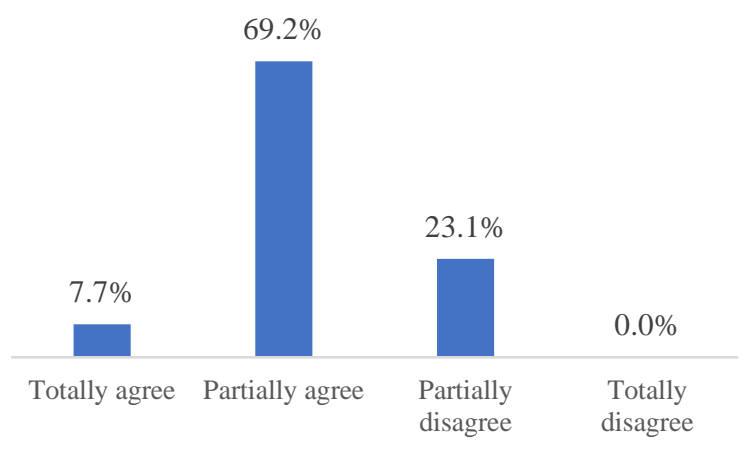

Figure 5 Percentage of workers who find less risk in the task performed

Question number twenty of the questionnaire: "Have adjustments been made to the functions and tasks in your position in order to reduce the risk of illness or accident?" presents a result that shows that $65 \%$ are "Partially agree", 27\% are "Partially disagree" and $8 \%$ are "Totally agree" as shown in Figure 6 , this tells us that their majority of the subjects under study (73\%) have made adjustments to the functions and tasks in their position in order to reduce the risk of illness or accident while $27 \%$ have not made adjustments to their functions or tasks on a regular basis in your position in favor of reducing the risk of illness or accident.

ISSN 2444-4987

ECORFAN@ All rights reserved

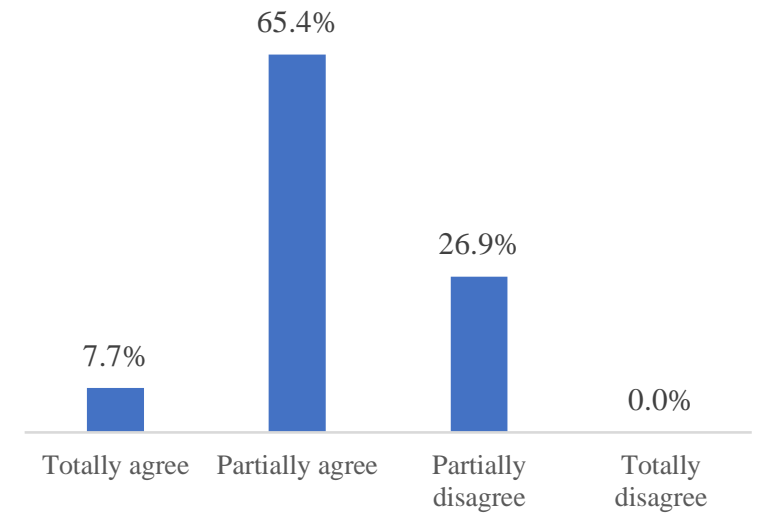

Figure 6 Percentages of perception of risk or illness of the worker in the work area

Question number twenty two of the questionnaire: "Have evaluations been made to determine the need to use elements that facilitate the work you do?" presents a result that shows that $54 \%$ are in "Partially disagree" and the other $46 \%$ are "Totally disagree" as shown in Figure 7 , this indicates that more than half of the subjects under study do not agree. An evaluation has been made to determine if they have the need to use elements that facilitate the work they do, while the remaining (46\%) have had no evaluation to determine the need to use elements that facilitate the work they do.

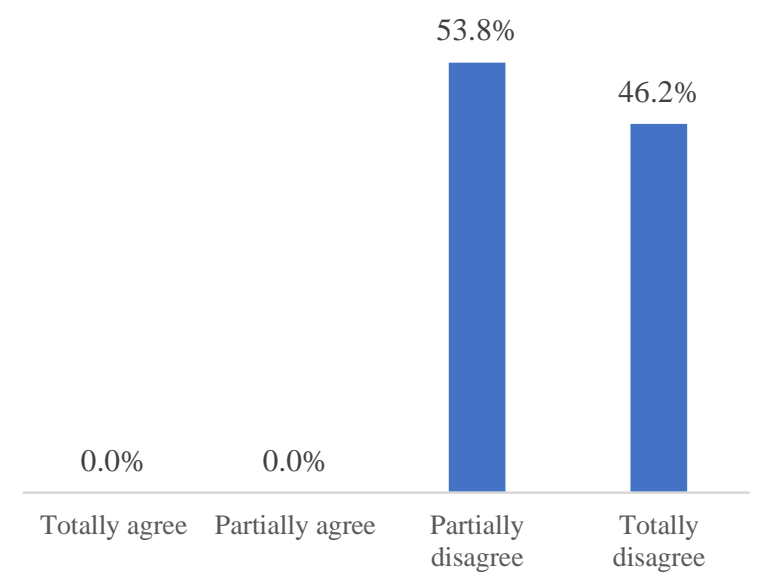

Figure 7 Percentage of workers who have not been evaluated to facilitate or reduce risk In tasks performed.

Question number twenty-three of the questionnaire: Do you use elements that facilitate the work that you do? " presents a result that shows that $96 \%$ are in "Totally disagree" while $4 \%$ are "Partially disagree" as shown in Figure 8 , this indicates that a large part almost entirely (96\%) of the Subjects under study do not use elements that facilitate the work they do, while the remaining (4\%) have used very little elements that help them to facilitate the work they do.

LÓPEZ-ACOSTA, Mauricio, CHACARA-MONTES, Allán, VELARDE-CANTÚ, José Manuel and RAMIREZ-CARDENAS, Ernesto. Ergonomic culture level in managers and supervisors in manufacturing centers. Journal of Research and Development. 2021 


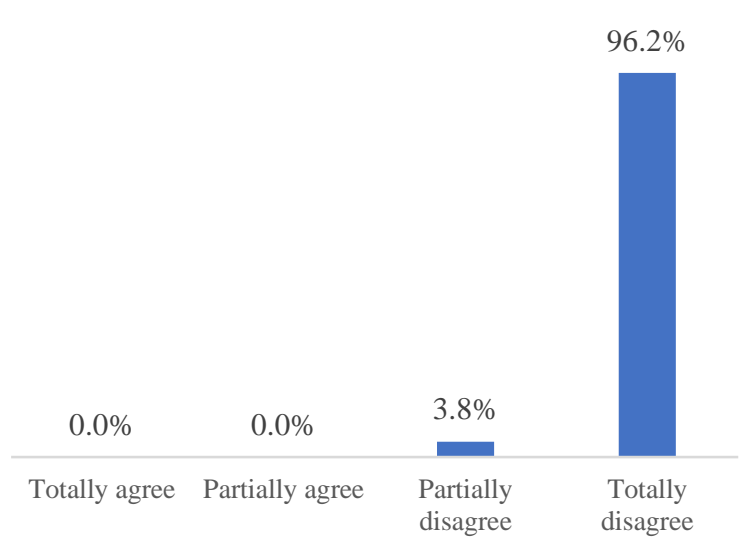

Figure 8 Percentage of workers who use a support tool in their work

\section{Conclusions and recommendations}

As a conclusion about this project, it can be said that the results of the survey are significant and show important results for the organization. In general, the results of the ergonomic culture in supervisors and managers in the company obtained a "High" rating, however it is important to make adjustments in processes and identify if the jobs, equipment and tools are suitable to develop their activities, with The purpose of reducing the risk that the employee suffers from a musculoskeletal disorder (MSD) disease or an occupational accident. Here are some recommendations:

Carry out an anthropometric study in order to have the information required to adapt the jobs to the capacities and limitations of their users (adapted to their anthropometric characteristics).

Carry out more frequently or more regularly the reinductions on the work carried out by the staff since it was shown that $50 \%$ do not receive reinductions in their work on a regular basis or in a way that is not entirely satisfactory.

Carry out more training or training since more than half of the subjects under study showed dissatisfaction with the training or training provided to improve their performance at the time of carrying out their work. Increase the number of evaluations that are made to the workspace, in the procedures, functions and tasks in order to find improvements to develop their tasks and reduce possible risks of illness or accidents.
It is also recommended to be constantly conducting inspections of areas, equipment and facilities seeking to identify the greatest number of conditions that represent the greatest risk to your safety and health in the workplace.

\section{References}

[1] AIE.(2021) What is ergonomics. Disponible en: https://iea.cc/what-is-ergonomics/

[2] Ardila-Jaimes, Claudia Patricia, \& Rodríguez-Amaya, Reynaldo Mauricio (2018). VALIDACIÓN DE UN CUESTIONARIO DE CULTURA ERGONÓMICA EN CENTROS DE TRABAJO CCE-T. Investigaciones Andina, 20(37), 115-135.

[3] ARSAM. (2020, 2 enero). "5 buenos ejemplos de la ergonomía en la industria automotriz | ARSAM". ARSAM | Herramientas industriales. https://www.arsam.es/5-buenosejemplos-de-la-ergonomia-en-la-industriaautomotriz/

[4] Guzman E., Saenz Zapata LM. (2010,10 noviembre). La ergonomía en el contexto de la prevención. Realidad y propuestas educativas. Memorias: 16a Semana de la Salud Ocupacional y 9o Congreso Colombiano de Ergonomía. Medellín (Colombia).

[5] Gomes, José Orlando (2014). El papel de la ergonomía en el cambio de las condiciones de trabajo: perspectivas en América Latina. Revista Ciencias de la Salud, 12( ),5-8

[6] Gómez-Conesa A., Martínez- González M. Ergonomía. Historia y ámbitos de aplicación, Fisioterapia. 2002;24(1):3-10.

[7] Millán, D. F. (2016,14 Noviembre). Proyecto Puente. "La importancia de la ergonomía en la salud ocupacional": https://proyectopuente.com.mx/2016/11/14/laimportancia-la-ergonomia-en-la-saludocupacional/

[8] Tapia, L. del C. S., Buenrostro, M. A. A., Cabrera, J. M. B., Pérez, J. E. T., \& Malagón, G. V. (2017). Análisis De Riesgo Ergonómico En Una Empresa Automotriz En México. European Scientific Journal, ESJ, 13(21), 419 